\title{
DIE NATURWISSENSCHAFTEN
}

\section{Speech at the Kepler Monument in Weil-der-Stadt ${ }^{1}$. \\ Von A. S. EdDington, Cambridge.}

It is a great privilege for many of us who have come from distant countries to join in this pilgrimage to the birthplace of JOHANNES KEPLER, and to do honour to the memory of the astronomer who propounded the laws of planetary motion.

Among the great pioneers of astronomy KEPLER seems to stand out as endowed with a most unusual type of mind. It was a most extraordinarily brilliant achievement to produce those three laws, so interdependent that the verefication of one turns on the verefication of the others. I doubt if it could have been done by any man whose mind moved on strictly orthodox scientific lines of reasoning. His predecessors by skilful development of recognised methods had brought astronomy to a certain stage. An intuition of a different kind was needed for the next stage. KEPLER was a strange erratic genius. His half fantastic way of thinking, capable as we know of preposterous misjudgments but nevertheless disciplined by scientific training, is scarcely such as we should extol as an example to be generally imitated, but it had the qualities needed to make this great advance.

I think it is not too fanciful to regard KEPLER as in a particular degree the forerunner of the modern theoretical physicist, who is now trying to reduce the atom to order as KEPLER reduced the solar system to order. It is not merely similarity of subject matter but a similarity of outlook. We are apt to forget that in the discovery of the laws of the solar system, as well as of the laws of the atom, an essential step was the emancipation from mechanical models. KEPLER did not proceed by thinking out possible devices by which the planets might be moved across the sky - the

1 Ansprache am KEPLER-Denkmal in Weil-der-Stadt an 20. Juli I928 aus Anlaß der 28. Versammlung der Astronomischen Gesellschaft in Heidelberg. wheels upon wheels of Ptolemy, or the whirling vortices of later speculation. I think that is how most of us would have attacked the problem; we should have hunted for some concrete mechanism to yield the observed motion, and have approached the laws of motion through an explanation of the motion. But KEPLER was guided by a sense of mathematical form, an aesthetic instinct for the fitness of things. In these later days it seems to us less incongruous that a planet should be guided by the condition of keeping the Action a minimum than that it should be pulled and pushed by concrete agencies. In like manner KEPLER was attracted by the thought of a planet moving so as to keep the growth of area steady - a suggestion which more orthodox minds would have rejected as too fanciful. I wonder how this abandonment of mechanical conceptions struck his contemporaries. Were there some who frowned on these rash adventures of scientific thought, and felt unable to accept the new kind of law without any explanation or model to show how it could possibly be worked? After KEPLER came NEwTON, and gradually mechanism came into predominance again. It is only in the latest years that we have gone back to something like KEPLERs outlook, so that the music of the spheres is no longer drowned by the roar of machinery.

Two years ago the Gesellschaft visited the Observatory of TYcho BRAHE in the island of Hven. It is a happy coincidence that has fixed our meeting this year near the birthplace of KEPLER; so that in consecutive meetings we have had vividly before us, first the observations, and then their fruition. It is good to have in the midst of our deliberations on the ever advancing frontiers of modern astronomy a brief respite to salute the great men of the past.

\section{Kepler und seine Erklärung des Sehvorganges.}

\section{Von Moritz von RoHr, Jena.}

Wie die Griechen mit der Zergliederung des Auges den Anfang machten, so haben sie auch versucht, sich den Sehvorgang zu erklären. Eine zusammenfassende Darstellung ging jedenfalls von Claudius Ptolemaeus (*Ioo, $\dagger$ I 78 ) aus, und er hat damit den ersten Abschnitt seines optischen Lehrbuches angefüllt. Leider ist dieser erste Abschnitt nicht auf uns gekommen, denn die aus einer arabischen Fassung im zwölften Jahrhundert in das Lateinische übertragenen Reste enthalten ihn nicht: er fehlte bereits bei den dafür benutzten arabischen Handschriften. Immerhin kann man aus manchen Äußerungen der späteren Abschnitte auf den ersten zurückschließen, und auch der Philosoph DAmIANUs (aus dem dritten oder vierten Jahrhundert unserer Zeitrechnung) teilt zum Sehvorgang einiges dem Ptolemaevs entlehnte mit.

Man wird danach annehmen dürfen, daß Prolemaeus auf das Augeninnere wenig Wert legte, da er das Sehen noch durch Strahlen vom Auge aus (Fühlfädentheorie) zustande kommen 